(c) American Dairy Science Association, 2007.

\title{
Effect of Photoperiod in the Third Trimester of Gestation on Milk Production and Circulating Hormones in Dairy Goats
}

\author{
S. J. Mabjeesh, ${ }^{\star 1}$ O. Gal-Garber, ${ }^{*}$ and A. Shamay† \\ *Department of Animal Sciences, Faculty of Agricultural, Food and Environmental Quality Sciences, The Hebrew University of Jerusalem, \\ P.O. Box 12, Rehovot 76100, Israel \\ †Agricultural Research Organization, Volcani Center, Institute of Animal Science, Bet Dagan 50250, Israel
}

\section{ABSTRACT}

Multiparous Israeli Saanen goats $(\mathrm{n}=8)$ were blocked at dry off (approximately $45 \mathrm{~d}$ prepartum) into 2 treatments of 4 goats each based on body weight (BW), previous milk production, and the number of detected embryos in utero. Treatments consisted of long-day (16 $\mathrm{h}$ light:8 h dark) and short-day ( $8 \mathrm{~h}$ light:16 h dark) photoperiods at normothermic ambient temperature $\left(22^{\circ} \mathrm{C}, 72 \%\right.$ relative humidity). All goats were returned to ambient photoperiod after kidding, milked twice daily, and milk yield was automatically recorded. Dry matter intake was similar between treatments and averaged $980 \mathrm{~g} / \mathrm{d}$. Milk production was greater in the short-day than in the long-day treatment (2,932 vs. $2,320 \mathrm{~g} / \mathrm{d}$ ) during the 12 -wk experimental period. Milk protein and lactose contents were similar in both treatments and averaged 3.61 and $4.88 \%$, respectively, whereas milk fat was greater in the long-day treatment $(4.80$ vs. $4.22 \%)$. Plasma insulin-like growth factor 1 was greater in the long-day treatment (149 vs. $73 \mathrm{ng} /$ $\mathrm{mL}$ ) during the dry period than in the short-day treatment, but was similar postkidding, averaging $76 \mathrm{ng} /$ $\mathrm{mL}$. Concentrations of triiodothyronine in plasma were similar in both treatments during the dry period, but greater during lactation in the short-day treatment (122.1 vs. $94.1 \mathrm{ng} / \mathrm{mL}$ ). Plasma prolactin was greater in the long-day than in the short-day treatment during the dry period ( 28.0 vs. $17.5 \mathrm{ng} / \mathrm{mL}$ ), whereas it was similar throughout lactation $(11.7 \mathrm{ng} / \mathrm{mL})$. These data support the idea that greater milk production in goats exposed to short days during the dry period is not explained by differences in feed intake or increased secretion of insulin-like growth factor 1 .

Key words: photoperiod, prolactin, dairy goat, dry period

\section{INTRODUCTION}

Caprine milk production is gaining in importance worldwide. Dairy goat farming for milk and cheese is

Received February 13, 2006

Accepted August 23, 2006.

${ }^{1}$ Corresponding author: Mabjeesh@agri.huji.ac.il increasing in Israel and the Mediterranean region. In contrast to dairy cows, goats have seasonal reproductive cycles, but little information is available with regard to the effects of photoperiod on milk production and quality.

In the dairy cow industry, use of photoperiod management is of great interest because it is a safe, noninvasive, and effective method of increasing milk production that can be used throughout the lactation cycle. Dairy cows exposed to a short-day photoperiod (SDPP) during the dry period produce more milk than cows exposed to long days. Long-day photoperiod (LDPP; $16 \mathrm{~h}$ light:8 $\mathrm{h}$ dark) during lactation increases daily milk yield by an average of $2 \mathrm{~kg} / \mathrm{cow}$ compared with cows held under natural photoperiod (Dahl et al., 2000). Milk composition is generally unaffected by photoperiod, although some studies have indicated a slight depression in milk fat content when dairy cows are exposed to LDPP (Dahl et al., 1997; Miller et al., 1999). Dry matter intake usually increases when dairy cattle are exposed to LDPP to support the demands of the mammary gland, which increases in response to this photoperiodic regimen (Dahl et al., 2000).

Prolactin (PRL) emerged as the initial candidate responsible for the galactopoietic effects of photoperiod. Indeed, long days increase circulating concentrations of PRL in a number of species including cattle (Peters and Tucker, 1978; Tucker et al., 1984). Prolactin has a galactopoietic role in dairy cows similar to a number of species, and is believed to be a mediator of the photoperiodic effect (Dahl et al., 2000). This effect occurs in dairy cows only during the periparturient period. Insulin-like growth factor 1 is another hormone that shows fluctuating concentrations in the circulation in response to photoperiodic treatment, independent of growth hormone, and could explain the effects of long days (Dahl et al., 2000). Long days also increase mammary parenchymal growth relative to short days (Petitclerc et al., 1984), and IGF-I increases bovine mammary growth in vitro (Shamay et al., 1988; McGrath et al., 1991). In contrast, SDPP inhibits the effect stimulated by LDPP, which could be related to IGF-I in cattle (Dahl et al., 2000). 
Treating dairy cows during the dry period (i.e., the third trimester) with LDPP increases PRL concentration, whereas SDPP ( $8 \mathrm{~h}$ light:16 h dark) decreases it (Linzell, 1973; Auchtung et al., 2005). Because a robust preparturient PRL surge is important to complete lactogenesis at calving (Tucker, 2000), LDPP was expected to increase milk production. Results from the latter study, however, revealed that SDPP increases milk production in the subsequent lactation by much as 3.2 $\mathrm{kg} / \mathrm{d}$ compared with cows held under LDPP when dry (Linzell, 1973). Thus, appropriate manipulation of photoperiod can dramatically improve the performance of dairy cows.

Similar to dairy cattle, a greater milk yield response to LDPP has been reported in ewes (Bocquier, 1985) and goats (Linzell, 1973; Terqui et al., 1984). In fact, the response was larger than that usually observed in cattle $(+20 \%)$. Little work, however, has focused on the influence of environmental modulation during the dry period, and its potential to affect subsequent milk yield in dairy goats. Recently, it was reported that an SDPP during the dry period is stimulatory to milk yield during the subsequent lactation, and that the effect persists throughout lactation (Aharoni et al., 2000). To the best of our knowledge, however, only limited data are available regarding the influence of LDPP during an established lactation, and none on the effect of SDPP during the dry period. The purpose of this study was therefore to examine the effect of a photoperiod treatment during the dry period on subsequent milk production and plasma hormonal profiles in dairy goats.

\section{MATERIALS AND METHODS}

\section{Cows and Treatments}

Multiparous Israeli Saanen goats $(n=8)$ in mid to late lactation were synchronized and inseminated to ensure their pregnancy. These goats were blocked at dry off ( $\sim 45 \mathrm{~d}$ prepartum) into 2 treatments of 4 goats each based on BW, previous milk production, and the number of detected embryos in utero. Treatments were LDPP (16 h light: $8 \mathrm{~h}$ dark) and SDPP ( $8 \mathrm{~h}$ light:16 h dark) at normothermic ambient temperature $\left(22^{\circ} \mathrm{C}\right.$, $72 \%$ relative humidity). All goats were maintained under ambient photoperiod until the onset of treatment. During the experimental period, goats were housed in metabolism cages equipped with automatic feeders in 2 separate but identical environmentally controlled rooms (photophase light intensity $=350 \mathrm{~lx}$ at eye level of the goats) in which photoperiod was adjusted according to the treatment. Goats were fed a diet that adequately met their nutritional demands for maintenance and gestation stage. Feed was offered in 12 equal meals by automatic feeder. The diet consisted of com- mercial pellets containing $16 \% \mathrm{CP}, 29.1 \% \mathrm{NDF}$, and 1.6 Mcal of $\mathrm{NE}_{\mathrm{L}}$ on a DM basis (Mixture 1471, Matmor Ltd., Ashdod, Israel), and chopped clover and vetch hay with $14.9 \% \mathrm{CP}, 47.5 \% \mathrm{NDF}$, and $1.1 \mathrm{Mcal}$ of $\mathrm{NE}_{\mathrm{L}}$. The hay supplied $60 \%$ of the daily DMI.

Dry matter intake was monitored while the goats were in the metabolism cages, and was adjusted to allow $10 \%$ refusals. Apparent digestibility of DM, OM, and $\mathrm{CP}$ was measured during a 5 -d collection period after 4 wk in the metabolic rooms. At kidding, all goats were returned to ambient photoperiodic conditions and a normal management regimen. Goats were milked twice daily at 0700 and $1900 \mathrm{~h}$, and daily milk production was recorded by automatic milk meter (Free-flow, S.E.R., Netanya, Israel). Pellets were offered in the milking parlor ad libitum and the hay was then offered in the yards to supply $35 \%$ of the total daily DMI.

Blood samples were collected on several occasions relative to kidding date (i.e., every $7 \mathrm{~d}$ from -45 to +45 d). Blood $\mathrm{pH}$ and $\mathrm{Na}$ concentration were measured in fresh samples by the ABL70 system (Radiometer, Copenhagen, Denmark). Plasma was then separated and stored at $-20^{\circ} \mathrm{C}$ for later analysis of PRL, IGF-I, and triiodothyronine (T3). Milk composition was quantified weekly by a near infrared procedure (Milkoscan 605; Foss Electric, Hillerød, Denmark). Postkidding data were collected for $120 \mathrm{~d}$ postpartum, which was deemed sufficient time to detect any treatment differences.

\section{Hormone Analyses}

Blood samples $(10 \mathrm{~mL})$ were collected from each goat between 0830 and $1030 \mathrm{~h}$ via jugular venipuncture into a sterile evacuated tube containing sodium heparin (Vacutainer, Becton Dickinson and Co., Franklin Lakes, $\mathrm{NJ}$ ), and immediately placed on ice. Plasma was harvested by centrifugation at $1,850 \times g$ for $20 \mathrm{~min}$ at $4^{\circ} \mathrm{C}$ and stored at $-20^{\circ} \mathrm{C}$ until use.

The IGF-I RIA was performed as previously described (Plaut et al., 1991). Briefly, $250 \mu \mathrm{L}$ of plasma was extracted with $300 \mu \mathrm{L}$ of glycyl-glycine $\mathrm{HCl}(0.1 M, \mathrm{pH}$ 2) at $37^{\circ} \mathrm{C}$ for $24 \mathrm{~h}$. To $275 \mu \mathrm{L}$ of assay buffer $(0.15 \mathrm{M}$ sodium phosphate, $0.02 \%$ protamine sulfate, $0.2 \% \mathrm{BSA}$, 0.02 sodium azide, $\mathrm{pH} 7.5$ ) were added $25 \mu \mathrm{L}$ of the extracted plasma and $100 \mu \mathrm{L}$ of anti-hIGF-I (NIH, Bethesda, MD). After $1 \mathrm{~h}$ at room temperature, $100 \mu \mathrm{L}$ of ${ }^{125}$ IGF-I $(20,000 \mathrm{cpm})$ was added and the tubes were incubated for $24 \mathrm{~h}$ at $4^{\circ} \mathrm{C}$. Then, $100 \mu \mathrm{L}$ of a second antibody, goat antirabbit IgG in PBS containing $0.2 \%$ normal rabbit serum was added and incubation continued for another $24 \mathrm{~h}$ at $4^{\circ} \mathrm{C}$. The hormone-antibody complex was precipitated by the addition of $1 \mathrm{~mL}$ of $12 \%$ polyethylene glycol 6000 and centrifugation for 30 $\min$ at $4^{\circ} \mathrm{C}$ at $3,000 \times g$. The supernatant was decanted 
and the assay precipitates were counted in a Kontron gamma counter with a log-logit program. Intra- and interassay coefficients of variation were 5.7 and $8.7 \%$, respectively.

Concentrations of T3 were determined by using a RIA kit from Diagnostic Products Corporation (Los Angeles, CA) according to the manufacturer's protocol. Intraand interassay coefficients of variation were 5.8 and $9.2 \%$, respectively.

The PRL RIA was performed as previously described (Miller et al., 1999). The assay was carried out with a primary antibody to PRL (AFPC35810691R; provided by A. F. Parlow, National Hormone and Peptide Program, Torrance, CA) diluted 1:50,000 in working solution and then to a final tube dilution of 1:200,000. Intraassay coefficient of variation was $6.1 \%$ and interassay coefficient of variation averaged $15.5 \%$. Assay sensitivity averaged $0.26 \mathrm{ng} / \mathrm{mL}$.

\section{Statistical Analyses}

Statistical analysis was performed using the mixed models procedures of SAS (Version 8.2, SAS Inst. Inc., Cary, NC). The model included treatment (LDPP vs. SDPP) and time as fixed variables, goat as the random variable, and their interaction. All dependent variables were included as repeated measures. No interaction effects were detected, so the model was reduced to include the main effects and the error term. Comparisons of means between treatments at various times (weeks of lactation) were performed using Student's $t$-test. Means are presented as least squares means.

\section{RESULTS}

\section{Goat Performance}

All goats were healthy throughout the experimental period and all of the kids were healthy. Dry matter, $\mathrm{OM}$, and CP intakes and digestibilities did not differ between treatments, averaging 980, 941, and $138 \mathrm{~g} / \mathrm{d}$ and 64,69 , and $60 \%$, respectively (Table 1 ).

Milk yield, monitored for 12 wk in lactation, was greater in goats exposed to SDPP than in goats exposed to LDPP (Figure 1). Milk yields began to differ during the second week of lactation, being greater $(P<0.001)$ in the SDPP treatment. Averaged over the monitored lactation period, milk yield in the SDPP goats was 612 $\mathrm{g} / \mathrm{d}$ greater than in the LDPP goats (Table 2). Milk fat concentration was affected by the treatments. It was greater in the LDPP than in the SDPP goats (Table 2). Milk protein concentration, on the other hand, did not differ between treatments and averaged $3.61 \%$. Milk, milk fat, and milk protein concentrations decreased with time. Milk lactose was similar for both treatments,
Table 1. Dry matter, OM, CP intake, and diet digestibilities during the dry period until parturition of dairy goats exposed to long-day photoperiod (LDPP; 16L:8D) or short-day photoperiod (SDPP; 8D:16L)

\begin{tabular}{|c|c|c|c|c|}
\hline & \multicolumn{2}{|c|}{ Photoperiod } & \multirow[b]{2}{*}{ SEM } & \multirow[b]{2}{*}{$P$-value } \\
\hline & LDPP & SDPP & & \\
\hline \multicolumn{5}{|c|}{ Intake, g/d } \\
\hline $\mathrm{DM}$ & 935 & 1,024 & 204 & 0.767 \\
\hline $\mathrm{OM}$ & 902 & 980 & 166 & 0.614 \\
\hline $\mathrm{CP}$ & 135 & 141 & 25.6 & 0.688 \\
\hline \multicolumn{5}{|c|}{ Digestibility, \% } \\
\hline DM & 66.6 & 61.4 & 3.37 & 0.098 \\
\hline $\mathrm{OM}$ & 70.3 & 67.3 & 2.94 & 0.496 \\
\hline $\mathrm{CP}$ & 62.2 & 57.8 & 2.61 & 0.376 \\
\hline
\end{tabular}

averaging $4.88 \%$, and was not influenced by time after kidding (Table 2).

\section{Plasma Hormones, $\mathrm{pH}$, and $\mathrm{Na}$}

Plasma hormones were measured from 7 wk before to 8 wk after kidding. Plasma T3 concentrations were similar between treatments at wk 7 prepartum, averaging $94.3 \mathrm{ng} / \mathrm{mL}$ (Figure 2). At kidding and up to $8 \mathrm{wk}$ thereafter, plasma T3 was greater in the SDPP goats, averaging $122.1 \mathrm{ng} / \mathrm{mL}$ vs. $94.1 \mathrm{ng} / \mathrm{mL}$ in the LDPP goats.

Plasma IGF-I was greater in the LDPP treatment than in the SDPP treatment from wk -7 to kidding, but did not differ at wk -4 and -6 (Figure 3 ). Concentration of IGF-I averaged 149 and $73 \mathrm{ng} / \mathrm{mL}$ for LDPP and SDPP treatments, respectively, before parturition, and did not differ between treatments during wk 1 to 8 postpartum, averaging $76 \mathrm{ng} / \mathrm{mL}$.

Concentration of PRL in plasma was greater in the LDPP animals than in their SDPP counterparts. Differ-

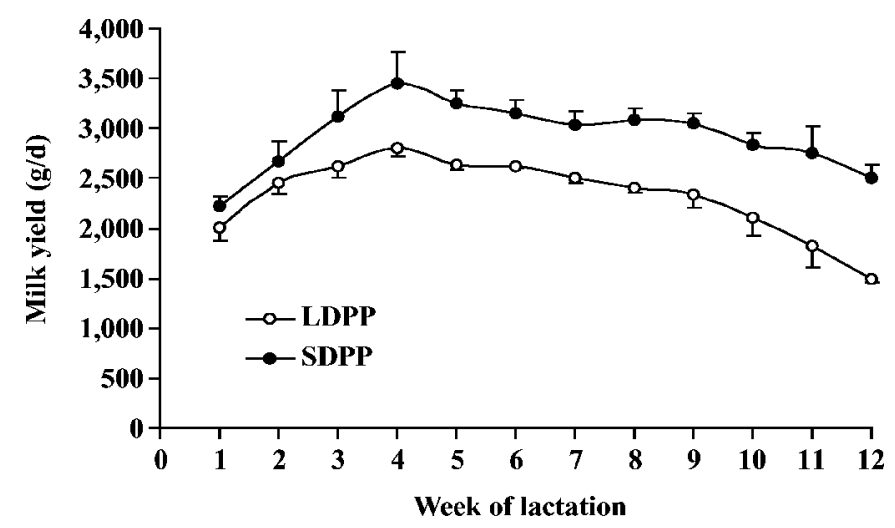

Figure 1. Milk yield of goats exposed to long-day photoperiod (LDPP) or short-day photoperiod (SDPP) during the third trimester of gestation. Average milk production differed $(P<0.001)$ for LDPP $(2,320 \mathrm{~g} / \mathrm{d})$ and $\operatorname{SDPP}(2,932 \mathrm{~g} / \mathrm{d})$ treatments $(\mathrm{SEM}=158)$; weeks of lactation also differed $(P<0.001)$. 
Table 2. Postpartum yield and composition of milk of dairy goats previously exposed to long-day photoperiod (LDPP) or short-day photoperiod (SDPP) during the third trimester of gestation

\begin{tabular}{|c|c|c|c|c|c|}
\hline & \multicolumn{2}{|c|}{ Photoperiod (PP) } & \multirow[b]{2}{*}{ SEM } & \multicolumn{2}{|c|}{$P$-value } \\
\hline & LDPP & SDPP & & $\mathrm{PP}$ & Week $^{1}$ \\
\hline Milk, g/d & 2,320 & 2,932 & 158 & 0.001 & 0.001 \\
\hline \multicolumn{6}{|c|}{ Milk composition, \% } \\
\hline Fat & 4.80 & 4.22 & 0.29 & 0.001 & 0.001 \\
\hline Protein & 3.56 & 3.65 & 0.21 & 0.261 & 0.001 \\
\hline Lactose & 4.91 & 4.85 & 0.08 & 0.036 & 0.31 \\
\hline
\end{tabular}

${ }^{1}$ Week $=$ Week of lactation .

ences differed $(P<0.01)$ from -5 to +1 wk relative to kidding (Figure 4). Both treatments exhibited a PRL surge at kidding, averaging 28 and $17.5 \mathrm{ng} / \mathrm{mL}$ for the LDPP and SDPP treatments, respectively. After kidding, during the second week of lactation, PRL concentration dropped to $11.7 \mathrm{ng} / \mathrm{mL}$ in both treatments.

Blood $\mathrm{pH}$ was similar between treatments and averaged 7.47 from wk -8 until parturition, and then decreased $(P<0.001)$ to 7.39 . Although this decrease in $\mathrm{pH}$ was significant, it did not reach or cause acidosis (Figure 5A). Concentration of $\mathrm{Na}$ in plasma did not differ between treatments (Figure 5B). It averaged 141 $\mathrm{m} M$ before kidding, and then decreased $(P<0.001)$ to $137 \mathrm{~m} M$ during wk 2; from wk 4 to $7, \mathrm{Na}$ averaged $138 \mathrm{~m} M$.

\section{DISCUSSION}

The purpose of this study was to test the hypothesis that exposing dairy goats to SDPP during the dry period would affect subsequent lactational performance, as ob-

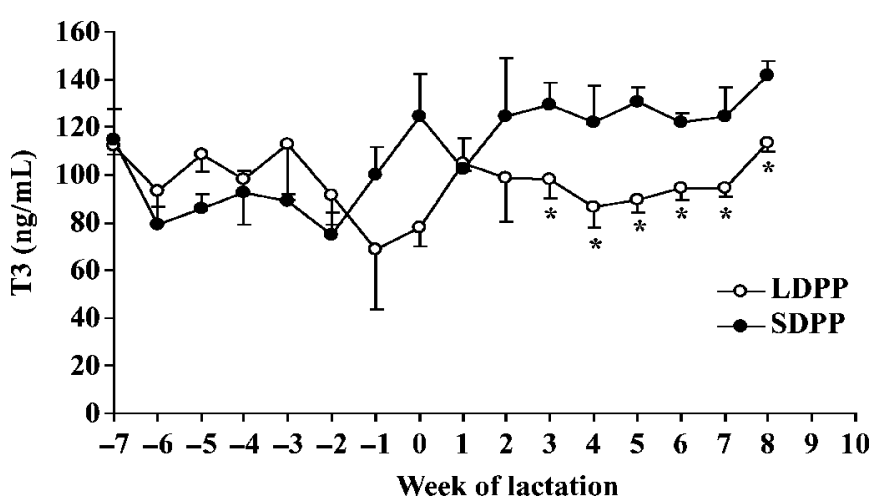

Figure 2. Plasma triiodothyronine (T3) concentration in goats exposed to long-day photoperiod (LDPP) or short-day photoperiod (SDPP) during the third trimester of gestation $(\mathrm{SEM}=9.51)$. Plasma T3 differed $(P<0.014)$ between photoperiod treatments and among weeks of lactation $(P<0.062)$. *Indicates differences between photoperiod treatments. served in dairy cows. Indeed, our results mirror those from dairy cows (Miller et al., 2000) in that LDPP during the dry period did not increase milk production in the following lactation compared with SDPP. In contrast, we found that exposure to SDPP during the dry period increased subsequent milk production, perhaps because hormonal changes influenced the mammary gland, rather than a general effect on feed intake.

Because DMI and nutrient digestibility during the dry period did not differ between treatments, the effect of photoperiod is likely mediated hormonally. In fact, exposing dairy cows to LDPP during lactation increases milk yield (Dahl et al., 1997), which supports the concept that long days are galactopoietic in cattle. Effects of long days on DMI in lactating cows are not always observed, but, generally in long-term studies, DMI increases to meet the increased demand for energy output from the mammary gland (Dahl et al., 2000). Similar photoperiodic effects have been reported for milk pro-

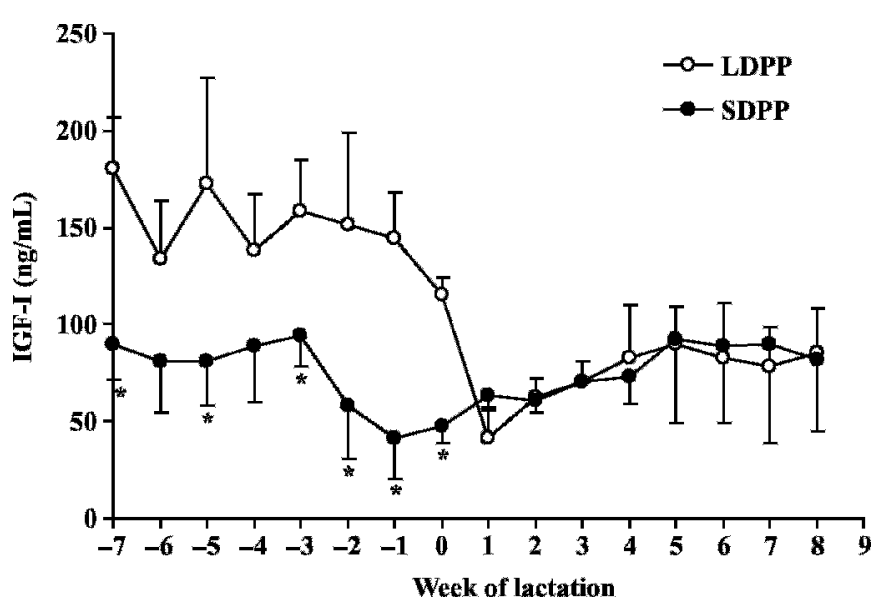

Figure 3. Plasma IGF-I concentration in goats exposed to longday photoperiod (LDPP) or short-day photoperiod (SDPP) during the third trimester of gestation. Average plasma IGF-I concentration was 0.110 and $0.082 \mathrm{ng} / \mathrm{mL}$ in LDPP and SDPP treatments, respectively (SEM $=0.22)$. Treatments differed $(P<0.01)$ and weeks of lactation differed $(P<0.001)$. *Indicates differences between photoperiod treatments. 


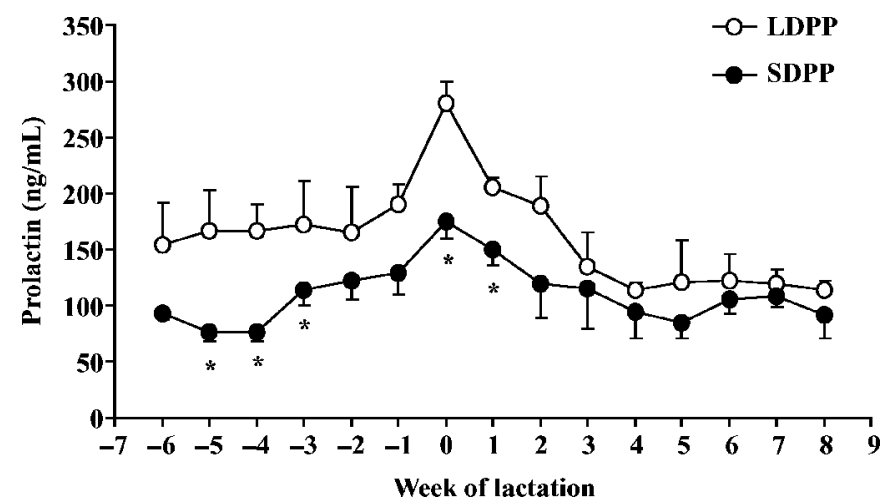

Figure 4. Plasma prolactin concentration of goats exposed to longday photoperiod (LDPP) or short-day photoperiod (SDPP) during the third trimester of gestation. Average plasma prolactin concentration was 15.6 and $11.8 \mathrm{ng} / \mathrm{mL}$ in LDPP and SDPP treatments, respectively (SEM $=2.27)$. Treatments differed $(P<0.01)$, but weeks of lactation did not differ. *Indicates differences between photoperiod treatments.

duction in ewes (Gootwine and Pollott, 2000) and goats (Linzell, 1973; Terqui et al., 1984). Milk yield in the present study, however, was $26 \%$ greater in the SDPP goats than in their LDPP counterparts.

Milk fat in the present study was affected by treatment, being greater (13.7\%) in LDPP than in SDPP
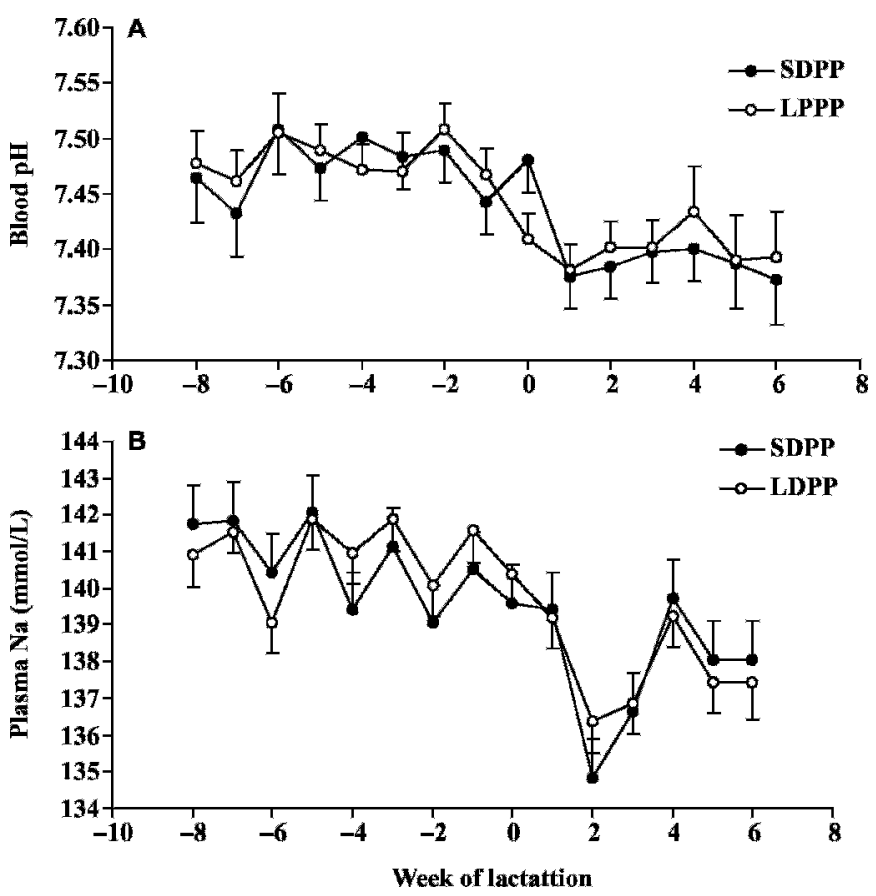

Figure 5. A) Blood $\mathrm{pH}$ in goats exposed to long-day photoperiod (LDPP) or short-day photoperiod (SDPP) during the third trimester of gestation differed $(P<0.0001)$ between treatments $(\mathrm{SEM}=0.02)$. B) Blood Na concentration in goats exposed to LDPP or SDPP during the third trimester of gestation did not differ between treatments (SEM $=1.48)$, but differed $(P<0.001)$ among weeks of lactation. treatments, whereas milk protein and lactose were not affected. Milk composition is generally unaffected by photoperiod, although results of some studies indicate that a slight depression in milk fat percentage may occur during exposure to long days (Stanisiewski et al., 1985). Although the mechanism governing this phenomenon was not determined in the present study, the increased milk production, which caused apparent greater DMI, especially the concentrate part of the diet, might explain the reduced fat in the SDPP treatment.

Exposing the goats to different photoperiodic regimens (i.e., LDPP vs. SDPP) resulted in changes in hormonal profiles. Hormones that were measured in the current study (T3, IGF-I, and PRL) were relevant to, and could explain, the differences in subsequent milk production. Concentration of T3 was greater in the SDPP treatment throughout lactation likely as a consequence of the greater metabolic demand. This profile (i.e., greater plasma T3 concentration postpartum in the SDPP treatment) parallels that of high-producing dairy cows, which have enhanced metabolic priority and nutrient partitioning to the mammary gland (Tucker, 2000). Similarly, this change has been observed in dairy cows that experience differences in postpartum metabolic adaptations upon onset of lactation (Reist et al., 2003). Moreover, plasma T3 concentration is lower in dairy cows that have reduced energy intake (Ronge et al., 1988). In the prepartum period, however, no difference in the metabolic demands occurred, as shown by equal DMI and T3 concentrations in plasma of goats in both treatments, Hence, T3 was not affected by photoperiod during the dry period.

Plasma IGF-I concentration was affected by photoperiod and was greater in goats exposed to LDPP compared with SDPP during the dry period. Nonetheless, IGF-I concentration was similar after kidding and during lactation in both treatments. There is strong evidence to support the hypothesis that long days stimulate IGF-I secretion in ruminants, providing a possible endocrine mechanism by which photoperiod effects on growth might be explained (Dahl et al., 2000). Photoperiod effects on growth have been shown in prepubertal heifers exposed to LDPP for 4 mo (Spicer et al., 1994). Those heifers consistently had greater circulating IGFI concentrations relative to those held under SDPP. Long days also increase mammary parenchymal growth relative to short days (Petitclerc et al., 1984). Concentrations of IGF-I further increase bovine mammary growth in vitro (Shamay et al., 1988; McGrath et al., 1991). Furthermore, IGF-I increased concomitantly with PRL when dairy cows were exposed to LDPP compared with SDPP during an established lactation (Dahl et al., 1997). It has also been reported that LDPP increases secretion of IGF-I rather than by altering clear- 
ance or via growth hormone-induced IGF-I stimulation. Thus, the galactopoietic effect of LDPP during an established lactation might be driven by the increased concentration of IGF-I in plasma (Dahl et al., 1997). In contrast, exposing dairy cows to LDPP during the dry period did not affect circulating IGF-I in plasma, which was similar to that in cows under SDPP (Miller et al., 2000). Nonetheless, milk yield was greater in the SDPP cows $(+3.2 \mathrm{~kg} / \mathrm{d})$ compared with LDPP cows. Taking these results together with the results of the current study, we suggest that the effect of manipulating photoperiod during the dry period is not mediated by changes in IGF-I in dairy goats (reduced in SDPP) or dairy cows (no difference between SDPP and LDPP).

Prolactin is critically important to the secondary stage of lactogenesis, which occurs at parturition (Akers, 1985). Prolactin is also necessary for complete differentiation of the bovine mammary secretory epithelial cells at the time of parturition (Akers et al., 1981a,b). Inhibition of the preparturient PRL surge by treatment with bromocriptine (CB154) resulted in a greater percentage of undifferentiated mammary epithelial cells compared with untreated controls (Akers et al., 1981b). Indeed, in this study goats exposed to SDPP had less plasma PRL than LDPP goats from wk 5 before to wk 1 postpartum and a parturient surge was observed. Hence, both treatments experienced the same pattern of PRL surge, although it was greater in the LDPP treatment; yet the subsequent milk production was greater in the SDPP treatment.

Prolactin secretion does not drive mammary growth during pregnancy (Tucker, 2000). Some of the mechanisms by which PRL induces lactogenesis in laboratory species involve binding to a specific receptor $(\mathbf{R})$ on the surface membrane of the mammary epithelial cell (Frantz et al., 1974; Tucker, 2000). Following R binding, a cascade of events is initiated that eventually induces transcription of genes that regulate the secretion of milk proteins (Tucker, 2000). Bovine tissues express at least 2 forms of PRL-R, the long and short forms (Schuler et al., 1997). It has been shown that photoperiod affects the concentrations of PRL and its receptors in different tissues in steers exposed to SDPP or LDPP (Auchtung et al., 2003). Steers exposed to LDPP had greater PRL concentrations and reduced PRL-R mRNA expression in the liver, mammary gland, and lymphocytes, whereas the opposite effect was observed in animals under SDPP. Recently, this inverse relationship between PRL concentration and PRL-R expression in the mammary gland was confirmed in dairy cows exposed to photoperiod treatments during the dry period (Auchtung et al., 2005). Furthermore, it was suggested that because PRL and PRL-R influence the mammogenic ability of mammary cells to produce milk compo- nents, it is likely that shifts in PRL sensitivity alter the extent of cellular differentiation during the postpartum period. Because all goats in the present study were moved to ambient photoperiod after kidding, it is possible that goats under SDPP expressed more PRL-R in the mammary gland, and the parturient PRL surge together with the shift in photoperiod caused dramatic stimulation of the parenchymal cells that led to a greater lactogenic response. Indeed, milk production began to differ between treatments at wk 3 postkidding, implying an effect of PRL binding to its receptors, which would initiate the observed lactogenic response.

Blood-electrolyte homeostasis is very tightly controlled and balanced in pregnancy and postpartum by hormones such as rennin, angiotensin, aldosterone, and glucocorticoids, as well as by nutritional status and filtration rate of the kidney (Robb et al., 1970). Hence, a plausible suggestion is that the slight decrease in plasma $\mathrm{Na}^{+}$concentration between pre- and postkidding is a reflux of the enlarged $\mathrm{Na}$ distribution pool, including the milk pool in the udder. The $\mathrm{pH}$ drop in the plasma postkidding compared with gestation is a direct effect of the increased consumption of the concentrate portion of the diet.

\section{CONCLUSIONS}

Exposure of dairy goats to SDPP during the dry period increased milk production during the subsequent lactation compared with LDPP exposure. Sensitivity to PRL, particularly during the transition to lactation, may be the mechanism underlying the greater milk yield observed throughout the subsequent lactation.

\section{ACKNOWLEDGMENTS}

This research was funded by the US-Israel Binational Agricultural Research and Development Fund (Award \#US-3201-01).

\section{REFERENCES}

Aharoni, Y., A. Brosh, and E. Ezra. 2000. Prepartum photoperiod effect on milk yield and composition in dairy cows. J. Dairy Sci. 83:2779-2781.

Akers, R. M. 1985. Lactogenic hormones: Binding sites, mammary growth, secretory cell differentiation, and milk biosynthesis in ruminants. J. Dairy Sci. 68:501-519.

Akers, R. M., D. E. Bauman, A. V. Capuco, G. T. Goodman, and H. A. Tucker. 1981a. Prolactin regulation of milk secretion and biochemical differentiation of mammary epithelial cells in periparturient cows. Endocrinology 109:23-30.

Akers, R. M., D. E. Bauman, G. T. Goodman, A. V. Capuco, and H. A. Tucker. 1981b. Prolactin regulation of cytological differentiation of mammary epithelial cells in periparturient cows. Endocrinology 109:31-40.

Auchtung, T. L., P. E. Kendall, J. L. Salak-Johnson, T. B. McFadden, and G. E. Dahl. 2003. Photoperiod and bromocriptine treatment 
effects on expression of prolactin receptor mRNA in bovine liver, mammary gland and peripheral blood lymphocytes. J. Endocrinol. 179:347-356.

Auchtung, T. L., A. G. Rius, P. E. Kendall, T. B. McFadden, and G. E. Dahl. 2005. Effects of photoperiod during the dry period on prolactin, prolactin receptor, and milk production of dairy cows. J. Dairy Sci. 88:121-127.

Bocquier, F. 1985. Influence de la photopériode et de la température sur certains équilibers hormonaux et sur les performances zootechniques de la brebis en gestation et en lactation. Thèse Doctorat Ingénieur, Institut National Agronomique Paris-Grignon, France.

Dahl, G. E., B. A. Buchanan, and H. A. Tucker. 2000. Photoperiodic effects on dairy cattle: A review. J. Dairy Sci. 83:885-893.

Dahl, G. E., T. H. Elsasser, A. V. Capuco, R. A. Erdman, and R. R. Peters. 1997. Effects of a long daily photoperiod on milk yield and circulating concentrations of insulin-like growth factor-1. J. Dairy Sci. 80:2784-2789.

Frantz, W. L., J. H. MacIndoe, and R. W. Turkington. 1974. Prolactin receptors: Characteristics of the particulate fraction binding activity. J. Endocrinol. 60:485-497.

Gootwine, E., and G. E. Pollott. 2000. Factors affecting milk production in improved Awassi dairy ewes. Anim. Sci. (Pencaitland) 71:607-615.

Linzell, J. L. 1973. Innate seasonal oscillations in the rate of milk secretion in goats. J. Physiol. 230:225-233.

McGrath, M. F., R. J. Collier, D. R. Clemmons, W. H. Busby, C. A. Sweeny, and G. G. Krivi. 1991. The direct in vitro effect of insulinlike growth factors (IGFs) on normal bovine mammary cell proliferation and production of IGF binding proteins. Endocrinology 129:671-678.

Miller, A. R., R. A. Erdman, L. W. Douglass, and G. E. Dahl. 2000. Effects of photoperiodic manipulation during the dry period of dairy cows. J. Dairy Sci. 83:962-967.

Miller, A. R., E. P. Stanisiewski, R. A. Erdman, L. W. Douglass, and G. E. Dahl. 1999. Effects of long daily photoperiod and bovine somatotropin (Trobest) on milk yield in cows. J. Dairy Sci. $82: 1716-1722$

Peters, R. R., and H. A. Tucker. 1978. Prolactin and growth hormone responses to photoperiod in heifers. Endocrinology 103:229-234.
Petitclerc, D., L. T. Chapin, and H. A. Tucker. 1984. Carcass composition and mammary development responses to photoperiod and plane of nutrition in Holstein heifers. J. Anim. Sci. 58:913-919.

Plaut, K., W. S. Cohick, D. E. Bauman, and R. C. Baxter. 1991. Evaluation of interference by insulin-like growth factor I (IGFI) binding proteins in a radioimmunoassay for IGF-I in serum from dairy cows. Domest. Anim. Endocrinol. 8:393-405.

Reist, M., D. Erdin, D. von Euw, K. Tschuemperlin, H. Leuenberger, C. Delavaud, Y. Chilliard, H. M. Hammon, N. Kuenzi, and J. W. Blum. 2003. Concentrate feeding strategy in lactating dairy cows: Metabolic and endocrine changes with emphasis on leptin. J. Dairy Sci. 86:1690-1706.

Robb, C. A., J. O. Davis, J. A. Johnson, E. H. Blaine, E. G. Schneider, and J. S. Baumber. 1970. Mechanisms regulating the renal excretion of sodium during pregnancy. J. Clin. Invest. 49:871-880.

Ronge, H., J. W. Blum, F. Clément, F. Jans, H. Leuenberger, and H. Binder. 1988. Somatomedin C in dairy cows related to energy and protein supply and to milk production. Anim. Prod. 86:165-183.

Schuler, L. A., R. J. Nagel, J. Gao, N. D. Horseman, and M. A. Kessler. 1997. Prolactin receptor heterogeneity in bovine fetal and maternal tissues. Endocrinology 138:3187-3194.

Shamay, A., N. Cohen, M. Niwa, and A. Gertler. 1988. Effect of insulin-like growth factor I on deoxyribonucleic acid synthesis and galactopoiesis in bovine undifferentiated and lactating mammary tissue in vitro. Endocrinology 123:804-809.

Spicer, L. J., B. A. Buchanan, L. T. Chapin, and H. A. Tucker. 1994 Effect of 4 months of exposure to various durations of light on serum insulin-like growth factor-1 (IGF-1) in prepubertal Holstein heifers. J. Anim. Sci. 72(Suppl. 1):178. (Abstr.)

Stanisiewski, E. P., R. W. Mellenberger, C. R. Anderson, and H. A. Tucker. 1985. Effect of photoperiod on milk yield and milk fat in commercial dairy herds. J. Dairy Sci. 68:1134-1140.

Terqui, M., C. Delouis, and R. Ortavant. 1984. Photoperiodism and hormones in sheep and goats. Pages 246-259 in Manipulation of growth in Farm Animals. J. F. Roche and D. O'Callaghan, ed. Martinus Nijhoff, The Hague, the Netherlands.

Tucker, H. A. 2000. Hormones, mammary growth, and lactation: A 41-year perspective. J. Dairy Sci. 83:874-884.

Tucker, H. A., D. Petitclerc, and S. A. Zinn. 1984. The influence of photoperiod on body weight gain, body composition, nutrient intake and hormone secretion. J. Anim. Sci. 59:1610-1620. 